\title{
22. Identification of the geochemical signatures of diffuse pollution in the Tellus Border soil data set, using source apportionment
}

\author{
Mark Cave, ${ }^{\mathrm{I}}$ Louise Ander ${ }^{\mathrm{I}}$ and Chris Johnson ${ }^{\mathrm{I}}$
}

How to cite this chapter:

Cave, M.R., Ander, E.L. and Johnson, C.C., 2016

'Identification of the geochemical signatures of diffuse pollution in the Tellus Border soil data set, using source apportionment' in M.E. Young (ed.), Unearthed: impacts of the Tellus surveys of the north of Ireland. Dublin. Royal Irish Academy.

DOI:10.3318/ 978-1-908996-88-6.ch22
The statistical process of 'self-modelling mixture resolution' has been used to identify chemical signatures of diffuse pollution in the topsoil samples of the Tellus Border geochemical survey, Ireland. Seventeen geochemical components were identified, of which nine were derived from underlying geology (high concentrations of trace metals suggest two of these are from mineralised sources), four were from secondary processes (iron oxides and carbonates) and four were associated with peat. One of the peat bog components has high concentrations of certain anthropogenic elements, probably from aerial deposition of anthropogenic particulates derived from modern industrialisation. The spatial extent of the diffuse pollution from aerial deposition in peat bogs has been mapped over the whole region.

\section{INTRODUCTION}

Several studies have used a multivariate statistical approach to interpret the inorganic analyses of soils in Ireland (Dempster et al., 2013; Zhang, 2006; Zhang et al., 2008). Zhang and colleagues' studies on the soils of Galway (Zhang, 2006) and one using the national soil database (Zhang et al., 2008) make particular use of the comparison of element distribution shapes to categorise elements followed by multivariate statistical methods, including principal component analysis and cluster analysis. In their study on soils in Galway, they identified that copper $(\mathrm{Cu})$, lead $(\mathrm{Pb})$, zinc $(\mathrm{Zn})$ and arsenic $(\mathrm{As})$ were coming principally from anthropogenic sources. In the study of the national soil database they identified nickel (Ni), Zn, cadmium (Cd), yttrium (Y), molybdenum (Mo), mercury $(\mathrm{Hg}), \mathrm{Pb}$ and antimony $(\mathrm{Sb})$ as probably coming from anthropogenic sources. The diffuse pollution study used here uses a self-modelling mixture resolution methodology to provide

${ }^{`}$ British Geological Survey, Keyworth. 


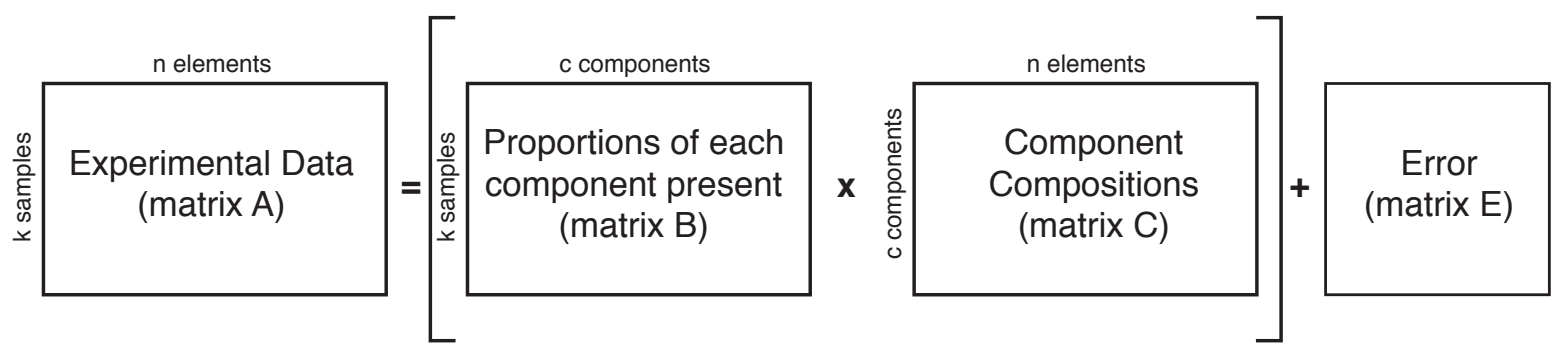

quantitative outputs that have been used to determine the sources of geochemical inputs in the Tellus Border soils.

\section{SElf-MOdelling MiXTURE RESOlution (SMMR)}

The SMMR methodology is fully described by Cave (2009); a brief overview follows. As the term 'self-modelling' implies, SMMR, in principle, does not require a priori any specific information concerning the data to resolve the pure variables. The basis for these techniques can be explained by reference to Fig. 22.1.

The data matrix A represents the experimental mixture data, which in this case are the combined total element data set of the 3475 Tellus Border soil samples analysed for 45 elements. The aim of SMMR is to arrive at the pure component information consisting of the proportions matrix (B) and the component composition matrix $(\mathrm{C})$ without any other information apart from that contained in the experimental data (A). In matrix notation this is:

$$
\mathrm{A}=\mathrm{BC}+\mathrm{E}(22.1)
$$

The method uses Varimax rotation of the principal component analysis (PCA) scores matrix, of the soils elemental compositions data (matrix A, equation 22.1), as a first approximation of the pure components proportions matrix. This is followed by iterative refining of the pure components matrices (B and $\mathrm{C}$, equation 22.1 ), applying non-negativity and mass balance constraints at each step. PCA produces a qualitative outcome in the form of series of abstract groupings in the data which can be open to subjective interpretation, whereas SMMR converts these to quantitative values and associated uncertainties that can be dealt with more objectively.
Figure 22.1. Graphical representation of the SMMR procedure. 
Figure 22.2. Element groupings based on the shapes of their data distributions.

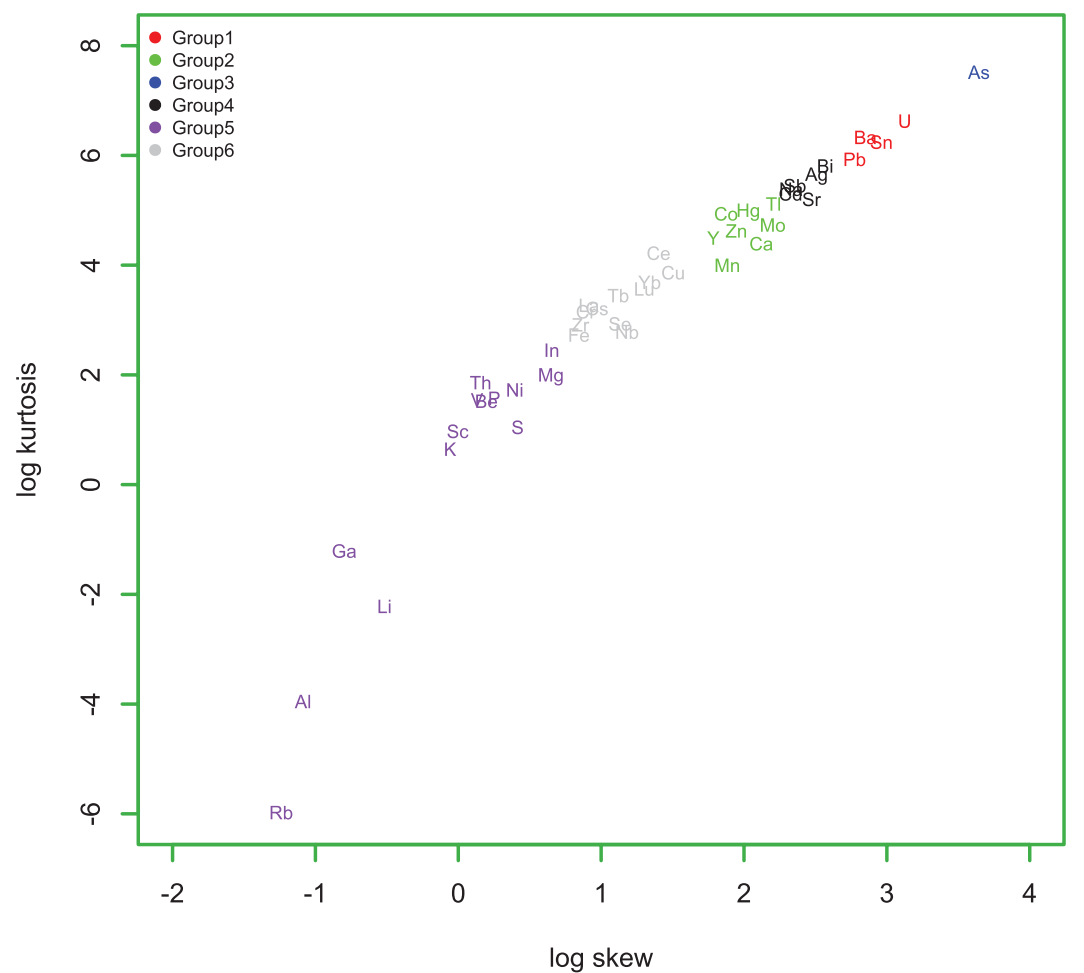

\section{Results AND DISCUSSION}

\section{Exploratory data analysis}

Only elements with more than $60 \%$ of the data greater than the detection limit were chosen. This set consisted of 45 elements (Al, Ba, Ca, Cr, Cu, Fe, K, Li, Mg, Mn, Na, Ni, $\mathrm{P}, \mathrm{S}, \mathrm{Sr}, \mathrm{V}, \mathrm{Zn}, \mathrm{Zr}, \mathrm{Ag}, \mathrm{As}, \mathrm{Be}, \mathrm{Bi}, \mathrm{Cd}$, Ce, Co, Cs, Ga, Hg, In, La, Lu, Mo, Nb, Pb, Rb, Sb, Sc, Se, Sn, Tb, Th, Tl, U, Y, Yb).

Recent studies (Ander et al., 2013) have shown that the shape of the data distributions is similar for elements derived from similar sources. In particular, elements derived from anthropogenic sources tend to have extended positive tails due to point source inputs. Using this approach, exploratory data analysis (EDA) of the relationships between elements was undertaken by assigning them to six groups, defined using k-means clustering of the shape of the data distributions, using a combination of the skew, octile skew, kurtosis, log skew and log kurtosis of the data distributions.

A plot of natural logarithm of the skew against natural logarithm of the kurtosis with the different element groupings is shown in Fig. 22.2. Moving from the bottom left to the top right of Fig. 22.2, the data distributions change from being broad symmetrical distributions to narrower, more positively skewed distributions with possible outliers in the distribution tail. The results are shown in Table 22.1. 


\section{Table 22.1. Element groupings identified by EDA using K-MEANS CLUSTERING OF DATA DISTRIBUTION PARAMETERS}

\begin{tabular}{|c|c|c|}
\hline $\begin{array}{l}\text { K-means } \\
\text { group }\end{array}$ & Elements & Comments \\
\hline 1 & $\mathrm{Ba}, \mathrm{Pb}, \mathrm{Sn}, \mathrm{U}$ & $\begin{array}{c}\text { Plots in the top right of Fig. } 22.2 \text { with long } \\
\text { right-hand tails are more likely to have a diffuse } \\
\text { pollution origin }\end{array}$ \\
\hline 2 & $\begin{array}{l}\mathrm{Ca}, \mathrm{Mn}, \mathrm{Zn}, \mathrm{Co}, \mathrm{Hg} \\
\mathrm{Mo}, \mathrm{Tl}, \mathrm{Y}\end{array}$ & $\begin{array}{l}\text { Plots in the centre of Fig. } 22.2 \text { with carbonates } \\
\text { and iron oxides }\end{array}$ \\
\hline 3 & As & $\begin{array}{c}\text { Plots in the top right of Fig. } 22.2 \text { with long } \\
\text { right-hand tails are more likely to have a diffuse } \\
\text { pollution origin }\end{array}$ \\
\hline 4 & $\mathrm{Na}, \mathrm{Sr}, \mathrm{Ag}, \mathrm{Bi}, \mathrm{Cd}, \mathrm{Sb}$. & $\begin{array}{c}\text { Plots in the top right of Fig. } 22.2 \text { with long } \\
\text { right-hand tails are more likely to have a diffuse } \\
\text { pollution origin }\end{array}$ \\
\hline 5 & $\begin{array}{l}\mathrm{Al}, \mathrm{K}, \mathrm{Li}, \mathrm{Mg}, \mathrm{Ni}, \mathrm{P} \\
\mathrm{S}, \mathrm{V}, \mathrm{Be}, \mathrm{Ga}, \mathrm{In}, \mathrm{Rb} \\
\text { Sc, Th }\end{array}$ & $\begin{array}{l}\text { Plots in the bottom left of Fig. } 22.2 \text {, associated } \\
\text { with geogenic, silicate and sulphide sources }\end{array}$ \\
\hline 6 & $\begin{array}{l}\mathrm{Cr}, \mathrm{Cu}, \mathrm{Fe}, \mathrm{Zr}, \mathrm{Ce} \\
\mathrm{Cs}, \mathrm{La}, \mathrm{Lu}, \mathrm{Nb}, \mathrm{Se} \\
\text { Tb, Yb }\end{array}$ & $\begin{array}{c}\text { Plots in the centre of Fig. } 22.2 \text { with carbonates } \\
\text { and iron oxides }\end{array}$ \\
\hline
\end{tabular}

While these results provide some insight into geochemical inputs to the soil, they need to be used in conjunction with other statistical approaches to provide more substantive interpretation of the evolution of soil geochemistry. This is provided by the SMMR analysis.

\section{SMMR}

SMMR modelling provides a more quantitative approach to identifying the number and chemical composition of the geochemical signatures in the soil samples. The SMMR analysis of the soil data sets suggests there are 19 underlying source components. This was determined by carrying out the SMMR algorithm on the data using an increasing number of components. The model with the minimum number of components required to reproduce the original data (i.e. not significantly different from the original data) was chosen. In order to ensure that the SMMR source components have physical meaning and are not artefacts of the data processing algorithm, it is necessary to put the SMMR source components into a geochemical context, making sure they are consistent with additional soil properties ( $\mathrm{pH}$ and loss on ignition (LOI)), geology and the related physical and human geography of the region. Each component was screened according to the following criteria. 
1. Does the SMMR source have a clearly defined chemical composition? Large uncertainties on the major and trace elements suggests that this may just be describing a 'noise component'.

2. Does the spatial extent of the SMMR source align with the underlying geology of the region, and is the geochemical composition consistent with the geology?

3. Does the SMMR source show a correlation to soil properties or to physical or human geographic parameters?

Examination of the SMMR sources with respect to criterion (1) removed two components having poorly defined chemical compositions and relatively low overall contribution to the overall extracted mass $(<1.4 \%)$. Under criterion (2) it was possible to clearly define the source of eight of the components as having been derived from the underlying geology. These are summarised in Table 22.2.

TABle 22.2. Summary OF GEOLOGICAL SOURCES IDENTIFIED IN THE SOIL CHEMISTRY: NAMES OF SOURCES INCLUDE ELEMENTS THAT MAKE UP MORE THAN IO\% OF THE SOURCE COMPOSITION

\begin{tabular}{c|c|c} 
SMMR source & Geology & Comments \\
\hline Al.Fe.Mg 1 & $\begin{array}{c}\text { Lower Palaeozoic, mostly associated with } \\
\text { the greywacke formation }\end{array}$ & \\
\hline Al.Fe.Mg & $\begin{array}{c}\text { Same as Al.Fe.Mg 1 but with higher } \\
\text { trace elements resulting from additional } \\
\text { mineralisation }\end{array}$ & High in K and Rb \\
\hline Fe.Al.K & $\begin{array}{c}\text { Clay } \\
\text { Ca.Al }\end{array}$ & $\begin{array}{c}\text { Mostly associated with the Tournasian } \\
\text { limestone formation }\end{array}$ \\
\hline Al.K.Mg & $\begin{array}{c}\text { Probably derived from weathering of } \\
\text { Dalradian aluminosilicates }\end{array}$ & $\begin{array}{c}\text { High concentration } \\
\text { of Zr }\end{array}$ \\
\hline Al.Fe & Underlying granites & High in Li, Th and U \\
\hline Fe.P & Namurian shales & High in Mo \\
\hline Mg.Fe & $\begin{array}{r}\text { Derived from weathering of Dalradian } \\
\text { aluminosilicate rocks }\end{array}$ & $\begin{array}{c}\text { High in rare earth } \\
\text { elements }\end{array}$ \\
\hline
\end{tabular}




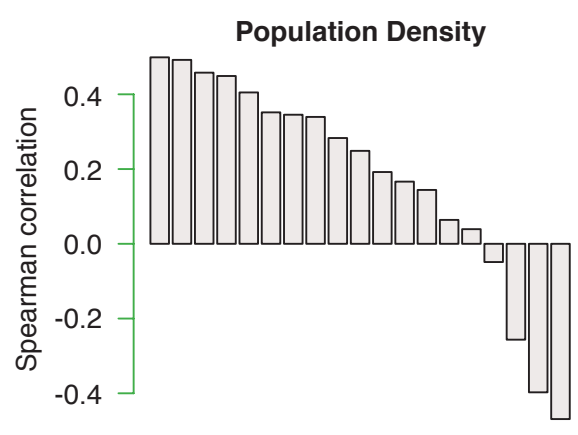

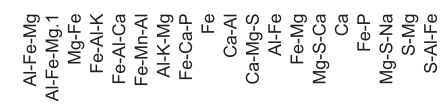

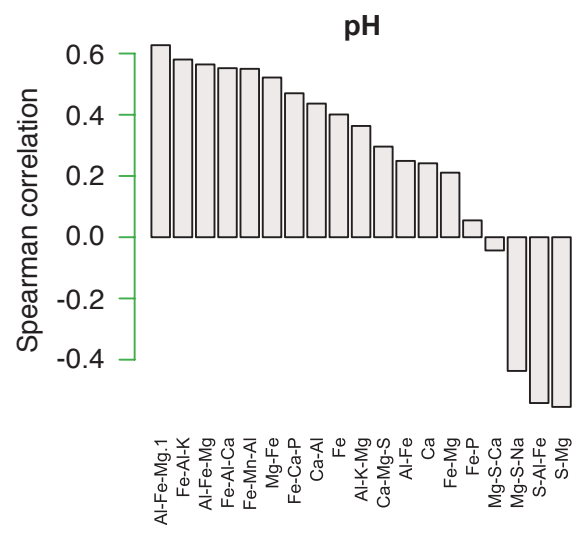

LOI
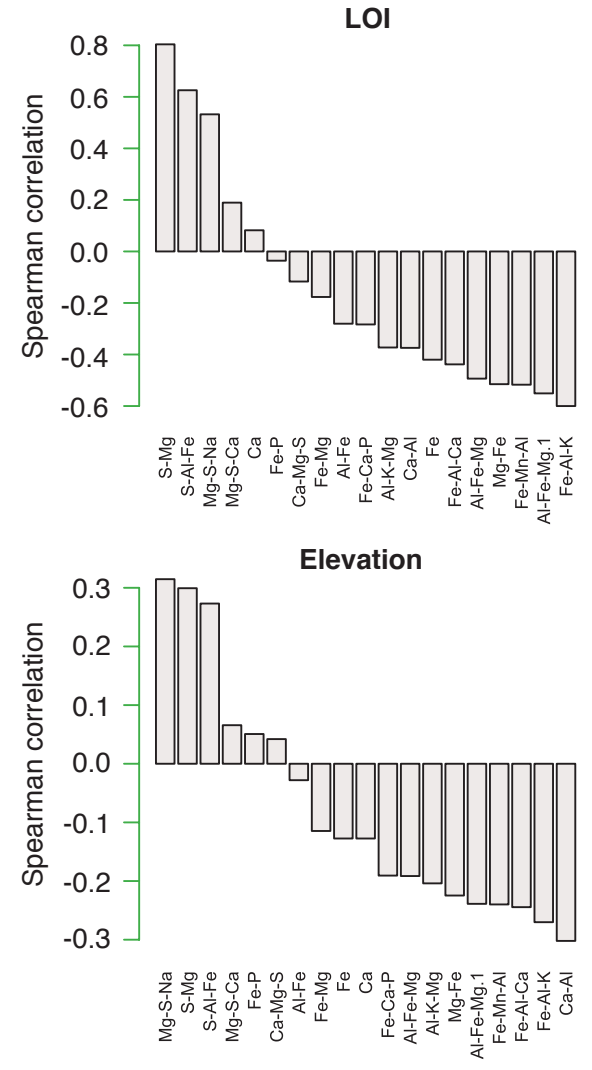

Figure 22.3. Spearman correlation of the mass of material associated with each component to population, LOI, $\mathrm{pH}$ and elevation.

TABle 22.3. Summary OF SOURCES IDENTIFIED IN THE SOIL CHEMISTRY RELATED TO SECONDARY PROCESSES: NAMES OF SOURCES INCLUDE ELEMENTS THAT MAKE UP MORE THAN IO\% OF THE SOURCE

\begin{tabular}{c|c|c} 
SMMR source & Source description & Comments \\
\hline Fe & $\begin{array}{c}\text { Made up of over 90\% iron: suggests that } \\
\text { this an Fe oxide source }\end{array}$ & $\begin{array}{c}\text { Occurs primarily in } \\
\text { localised regions of the } \\
\text { highlands of County } \\
\text { Donegal }\end{array}$ \\
\hline Fe.Mn.Al & Mixed Fe/Mn oxides (60\% Fe 20\% Mn) & $\begin{array}{c}\text { Occurs primarily in } \\
\text { localised regions of the } \\
\text { highlands of County } \\
\text { Donegal and counties } \\
\text { Sligo and Leitrim }\end{array}$ \\
\hline $\mathrm{Ca}$ & $\begin{array}{c}\text { Made up of over } 90 \% \text { Ca: suggests that this } \\
\text { is a Ca carbonate source }\end{array}$ & $\begin{array}{c}\text { Probably a marine } \\
\text { carbonate as it occurs } \\
\text { along the shoreline of } \\
\text { County Donegal }\end{array}$ \\
\hline
\end{tabular}


In addition to the underlying geology, three other components were identified from their chemical composition as being derived from secondary processes (Table 22.3): a source made up of over $90 \% \mathrm{Fe}$, suggesting that this is an iron (Fe) oxide; a source containing $60 \% \mathrm{Fe}$ and $20 \%$ manganese $(\mathrm{Mn})$, which is probably a mixed Fe/Mn oxide; and a source made up of over $90 \%$ calcium $(\mathrm{Ca})$, occurring almost exclusively along the shoreline of County Donegal, which suggests a marine calcium carbonate origin.

Correlations of the SMMR sources with soil properties and physical or human geographic parameters (Fig. 22.3) found four sources with high sulphur content and positive correlations with LOI and negative correlations with $\mathrm{pH}$ which, along with their spatial distributions, suggest that these are components associated with peat bogs (Table 22.4).

\section{TABle 22.4. Summary of SOURCES IDENTIFIED IN THE SOIL CHEMISTRY RELATED TO PEAT BOGS: NAMES OF SOURCES INCLUDE ELEMENTS THAT MAKE UP MORE THAN IO\% OF THE SOURCE COMPOSITION}

\begin{tabular}{|c|c|c|}
\hline SMMR source & Source description & Comments \\
\hline S.Mg & $\begin{array}{c}\text { Made up of over } 60 \% \mathrm{~S} \text { and } 15 \% \mathrm{Mg} \text { with } \\
\text { highest concentrations found along the coast } \\
\text { of County Donegal. High correlation with } \\
\text { LOI and elevation }\end{array}$ & $\begin{array}{c}\text { Relatively low } \\
\text { concentrations of } \\
\text { inorganic elements } \\
\text { suggest that this is a } \\
\text { high organic matter } \\
\text { content }\end{array}$ \\
\hline S.Al.Fe & $\begin{array}{l}\text { Made up of } 30 \% \mathrm{~S} \text { and Al. U content of } 0.1 \% \\
\text { High correlation with LOI and elevation }\end{array}$ & $\begin{array}{l}\text { Higher concentration } \\
\text { of inorganic elements } \\
\text { suggests higher ash } \\
\text { content }\end{array}$ \\
\hline Mg.S.Na & $\begin{array}{l}\text { Contains } 30 \% \mathrm{Mg} \text { and } \mathrm{S} \text { and } 3 \% \mathrm{~Pb} \text {. High } \\
\text { correlation with LOI and elevation }\end{array}$ & $\begin{array}{l}\text { High concentrations } \\
\text { of anthropogenically } \\
\text { derived elements suggest } \\
\text { aerial deposition }\end{array}$ \\
\hline Mg.S.Ca & $\begin{array}{l}\text { Contains } 30 \% \mathrm{Mg} \text { and } \mathrm{S} \text { and occurs } \\
\text { principally on the Carlingford peninsula, } \\
\text { Co. Louth. Has the lowest correlation with } \\
\text { LOI and elevation of the four components } \\
\text { associated with peat sources }\end{array}$ & \\
\hline
\end{tabular}

The SMMR sources have relatively low correlation coefficients $(<0.45)$ with population density (Fig. 22.3), indicating a lack of causative effect. There is no evidence of any major chemical fingerprint from areas of higher population, which is very much in contrast to England and Wales (Ander et al., 2013). 

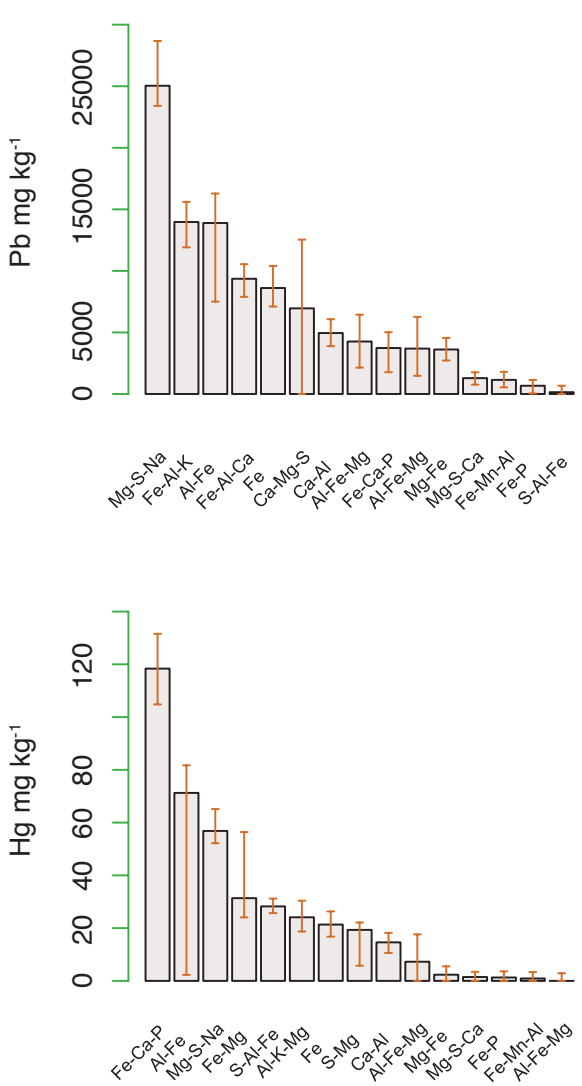
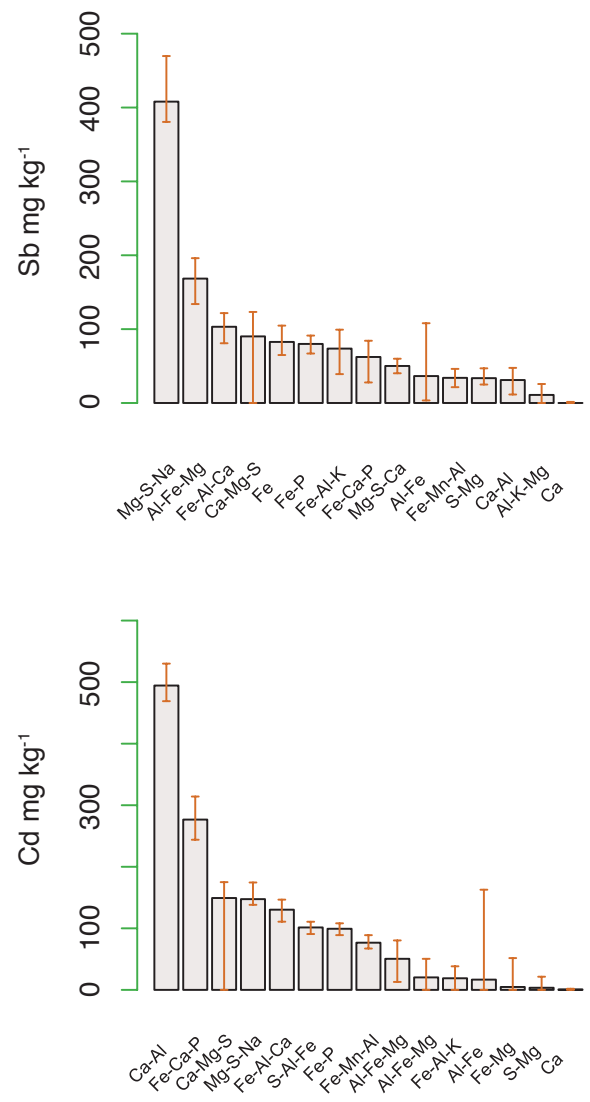

Table 22.5. Summary of SOURCES IDENTIFIEd IN THE SOIL CHEMISTRY WHOSE SOURCES ARE LESS CLEARLY IDENTIFIED; THE NAMES OF THE SOURCES ARE MADE UP FROM THOSE ELEMENTS THAT MAKE UP MORE THAN IO\% OF THE SOURCE COMPOSITION

\begin{tabular}{|c|c|c|}
\hline SMMR source & Source description & Comments \\
\hline Fe.Ca.P & $\begin{array}{c}\text { Made up of } 45 \% \mathrm{Fe}, 25 \% \mathrm{Ca} \text {, with high } \\
\text { concentrations of } \mathrm{Zn}, \mathrm{Pb} \text { and } \mathrm{Hg} \text {. Highest } \\
\text { concentrations found principally along the } \\
\text { edge of the greywacke formation in counties } \\
\text { Monaghan and Cavan }\end{array}$ & $\begin{array}{c}\text { Probably a mineralised } \\
\text { source }\end{array}$ \\
\hline Fe.Al.Ca & $\begin{array}{c}\text { Made up of } 40 \% \mathrm{Fe}, 30 \% \mathrm{Al} \text { with high } \\
\text { concentrations of As. Fairly widespread over } \\
\text { the Tellus Border region }\end{array}$ & $\begin{array}{l}\text { Probably a mixed } \mathrm{Fe} \\
\text { oxide }\end{array}$ \\
\hline
\end{tabular}

Figure 22.4. Mass distributions of $\mathrm{Pb}, \mathrm{Sb}, \mathrm{Hg}$ and Cd between the SMMR source components (error bars represent the 95 th percentile confidence limits). 
Figure 22.5. Mass distributions of As and U between the SMMR source components (error bars represent the 95th percentile confidence limits).
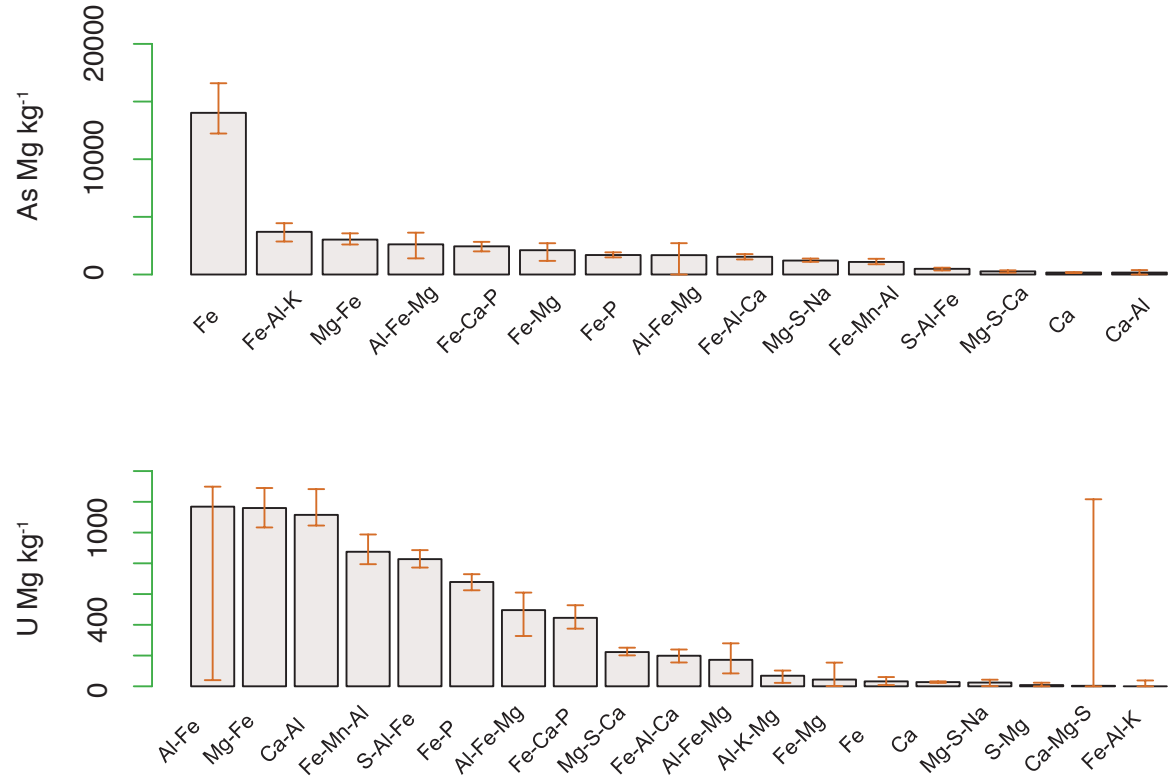

The origins of two of the source components were less easily defined (Table 22.5), but the Fe.Ca.P component is probably derived from mineralised underlying geology and the Fe.Al.Ca is possibly derived from a mixed Fe oxide phase in the soil.

Figures 22.4 and 22.5 show how the mass of selected elements, likely to be related to anthropogenic sources $(\mathrm{Pb}, \mathrm{Sb}, \mathrm{Hg}, \mathrm{Cd}$, As and $\mathrm{U})$, summed over all soil samples is distributed between the source components identified by the SMMR modelling along with 95th percentile error bars.

For lead and antimony (Fig. 22.4), the Mg.S.Na component identified as the possible diffuse pollution source in Table 22.4 has the highest single contribution to the overall mass inventory for these elements. For mercury (Hg) (Fig. 22.4) the mineralised component (Fe-Ca-P) has the highest contribution; taking account of the uncertainty, the next highest contribution is the diffuse pollution Mg.S.Na component.

Cadmium (Fig. 22.4) is associated with carbonate components, with the top two highest mass contributors being the Ca-Al limestone derived component and the Fe.Ca.P mineralised component and the next most significant being the Mg.S.Na diffuse pollution component.

Arsenic (Fig. 22.5) shows a very different but probably predictable mass distribution with Fe oxide as the main host for As in the soils, which is similar to studies in England which show that As is most often associated with Fe oxides (Palumbo-Roe et al., 2005). There is, however, a significant portion of the As associated with the diffuse pollution component. 

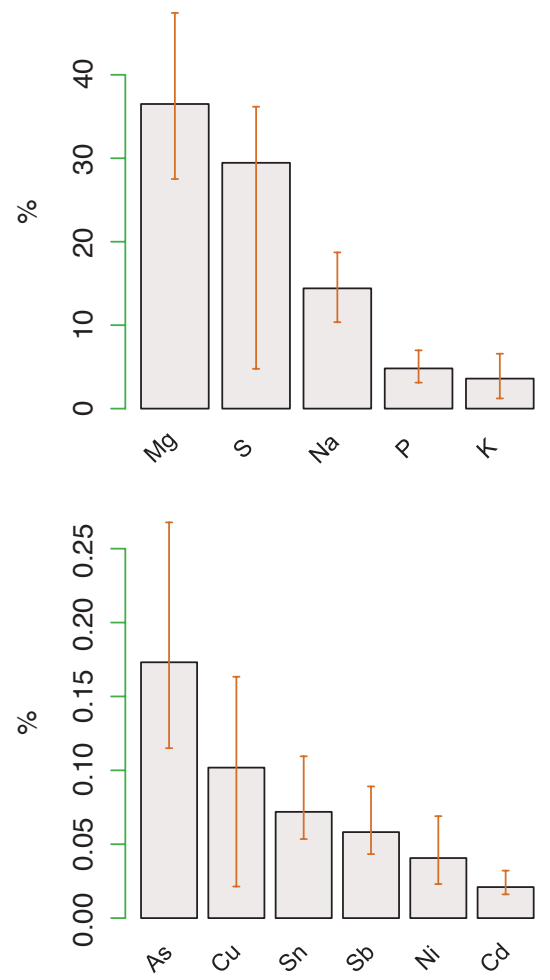
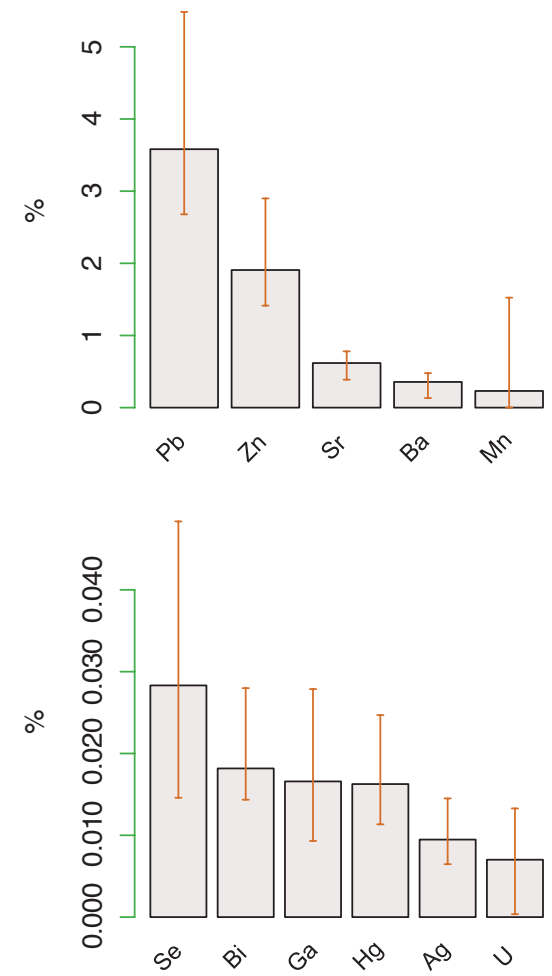

Finally uranium (Fig. 22.5) shows a pattern quite different from those of the other anthropogenically derived elements, with the highest concentrations associated with granites (Al.Fe), Dalradian aluminosilicates (Mg.Fe) and limestones (Ca.Al), and Fe/Mn oxides (Fe.Mn.Al). Interestingly, the next highest contribution is to the mineralised peat component (S.Al.Fe) but there is no significant $U$ content associated with the peat-derived

Figure 22.6. Chemical composition of the peat bog related diffuse pollution component (error bars represent the 95 th percentile confidence limits). diffuse pollution component.

\section{Identification of diffuse pollution}

The results of the SMMR analysis of the Tellus Border soils data suggest that most chemical sources that contribute to the soil chemistry are derived from three broad categories: the underlying geology; secondary processes such as the formation of Fe oxides and carbonates; and peat bogs. The anthropogenic pathfinder elements can be found occurring naturally in geologically derived components, particularly where mineralisation occurs, and in the case of As it occurs principally in Fe oxides.

One source (Mg.S.Na) with the highest positive correlation to elevation (Fig. 22.3) shows particularly high concentrations of anthropogenically derived elements (e.g. $\mathrm{Pb}$ 4\%, As $0.15 \%$, Sb $0.05 \%$, Cd 0.02 and $\mathrm{Hg} 0.01 \%$; Fig. 22.6). This source is thought to be related to peat bogs (Table 22.4) and has the highest individual contribution for the total $\mathrm{Pb}$ and $\mathrm{Sb}$ found in the Tellus Border soils. It is an important source for $\mathrm{Cd}$ and $\mathrm{Hg}$ 


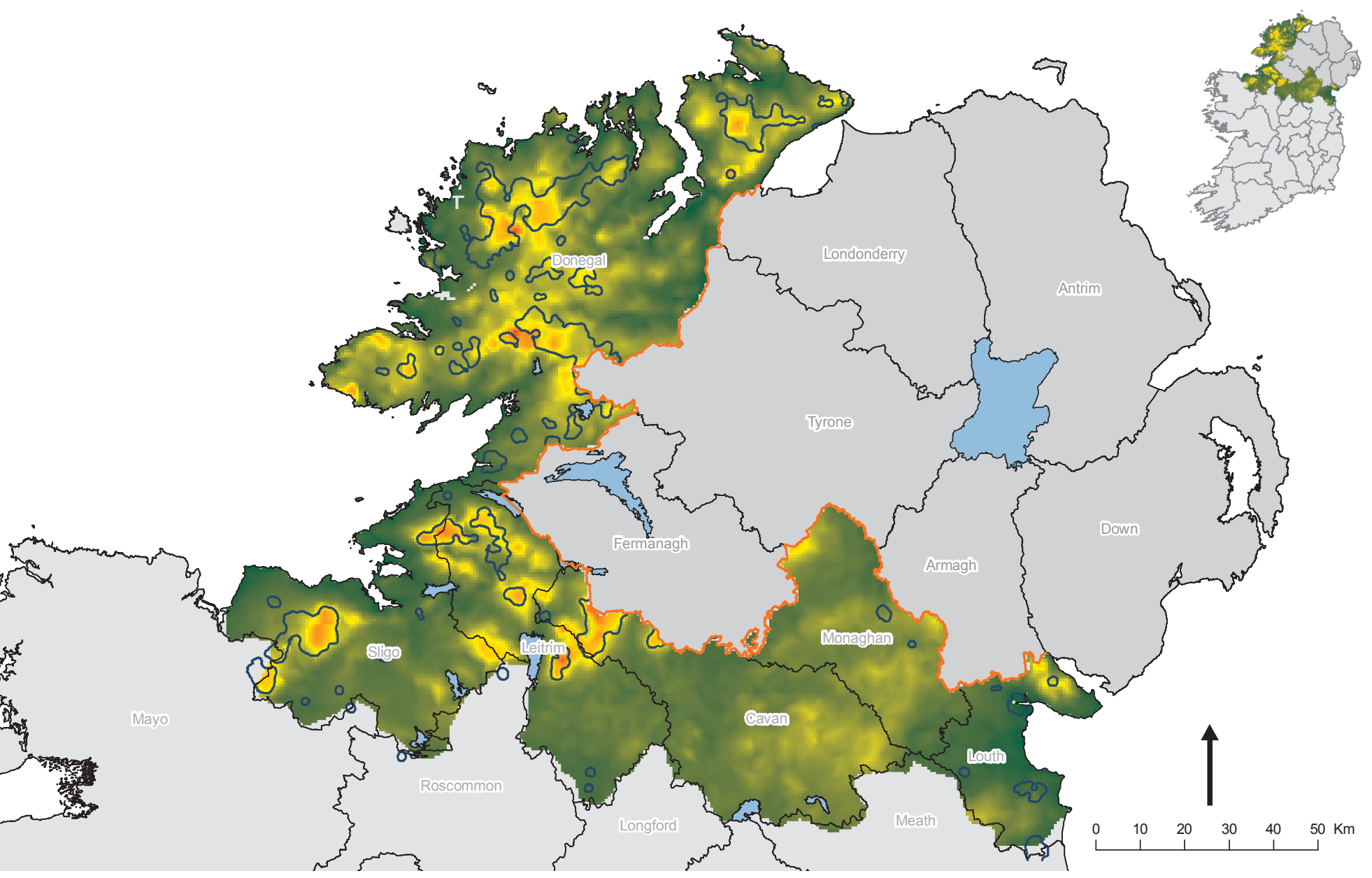

Figure 22.7. Suspected anthropogenic component (dark blue contour lines show where the component occurs at greater than $0.05 \%$ in the soil)

superimposed on the colourshaded elevation data, showing a close spatial match. but has less contribution to total As and U. Plotting the concentration of this source as a contour plot overlaying a colour map of elevation, Fig. 22.7 shows a close spatial match between high concentrations of the component and high elevation.

Peat records from ombrotrophic bogs (i.e. those fed with nutrients and pollutants from atmospheric inputs, rather than from streams) have been shown to provide valuable information about the atmospheric inputs of trace metals (e.g. Farmer et al., 2009; Shotyk, 1996). The SMMR component Mg.S.Na is therefore believed to be a peat-derived component containing aerial deposition of anthropogenic particulates.

A study of peat core just to the south of the Tellus Border region in counties Mayo and Galway (Coggins et al., 2006) showed elevated concentrations of $\mathrm{Cd}, \mathrm{Hg}$ and $\mathrm{Pb}$, which, when dated using $\mathrm{Pb}$ and $\mathrm{Cs}$ isotopes, were shown to be associated with recent anthropogenic pollution (1950-70) from aerial deposition. This suggests that the component dominated by an organic matter source, which is associated with high elevations, has trace element concentrations (Fig. 22.7) identified in this study which are expected to be similarly derived from aerial deposition of anthropogenic pollution onto peat uplands.

The source of the high concentrations of these pathfinder elements is subject to speculation. Coggins et al. (2006) comment that the prevailing wind direction across Ireland is from the Atlantic Ocean in the west, not from easterly winds, which suggests that the diffuse pollution is not from Britain and Northern Europe. They point out, however, that 
the peat core profiles are similar to those found in North America, and suggest that the anthropogenic pollution could be derived from this source.

The unique feature of this study is that the data have been derived from surface soil samples, not from a few core samples, so the spatial extent of the diffuse pollution from aerial deposition can be mapped over a large region.

\section{CONCLUSIONS: IMPLICATIONS FOR POLICY AND PLANNING}

The identification of both natural and anthropogenic inputs to soils in the Tellus Border area using the SMMR approach not only is scientifically interesting but also has practical use for environmental policy and planning at local and national scales in Ireland. The SMMR data interpretation has the potential to predict potential pollution problems that could occur; resolve newly identified or suddenly high-profile short- or long-term contamination problems to minimise the impact on the living ecosystem; recognise and quantify natural or human-induced changes in the future; and identify potential mineral resources.

\section{ACKNOWLEDGEMENTS}

This chapter is published with the permission of the Executive Director of the British Geological Survey (NERC).

\section{REFERENCES}

Ander, E.L, Johnson, C.C., Cave, M.R., Palumbo-Roe, B., Nathanail, C.P. and Lark, R.M., 2013 'Methodology for the determination of normal background concentrations of contaminants in English soil', Science of the Total Environment, 454-5, 604-18. Available at http://nora.nerc.ac.uk/501486/. http://dx.doi.org/10.1016/j.scitotenv.2013.03.005.

Cave, M.R., 2009 The Use of Self Modelling Mixture Resolution for the Interpretation of Geochemical Data. British Geological Survey Internal Report IR/08/035. Keyworth, UK. http://dx.doi.org/10.13140/2.1.4435.0245.

Coggins, A.M., Jennings, S.G. and Ebinghaus, R., 2006 'Accumulation rates of the heavy metals lead, mercury and cadmium in ombrotrophic peatlands in the west of Ireland', Atmospheric Environment, 40, 260-78.

Dempster, M., Dunlop, P., Scheib, A. and Cooper, M.R., 2013 'Principal component analysis of geochemistry of soils developed on till in Northern Ireland', Journal of Maps, 9, 3, 373-89. Available at http://nora.nerc.ac.uk/503933/. http://dx.doi.org/10.1080/17445647.2013.789414.

Farmer, J.G., Anderson, P., Cloy, J.M., Graham, M.C., Mackenzie, A.B. and Cook, G.T., 2009 'Historical accumulation rates of mercury in four Scottish ombrotrophic peat bogs over the past 2000 years', Science of the Total Environment, 407, 5578-88.

Palumbo-Roe, B., Cave, M.R., Klinck, B.A., Wragg, J., Taylor, H., O’Donnell, K. and Shaw, R.A., 2005 'Bioaccessibility of arsenic in soils developed over Jurassic ironstones in eastern England', Environmental Geochemistry and Health, 27, 121-30. Available at http://nora.nerc.ac.uk/15880/. http://dx.doi.org/10.1007/s10653-005-0128-1.

Shotyk, W., 1996 'Natural and anthropogenic enrichments of As, Cu, Pb, Sb, and Zn in ombrotrophic versus minerotrophic peat bog profiles, Jura Mountains, Switzerland', Water, Air, \& Soil Pollution, 90, 375-405.

Zhang, C., 2006 'Using multivariate analyses and GIS to identify pollutants and their spatial patterns in urban soils in Galway, Ireland', Environmental Pollution, 142, 501-11.

Zhang, C., Fay, D., McGrath, D., Grennan, E. and Caron, O.T., 2008 'Statistical analyses of geochemical variables in soils of Ireland', Geoderma, 146, 378-90. 
Unearthed: impacts of the Tellus surveys of the north of Ireland

First published in 2016 by the

Royal Irish Academy

19 Dawson Street

Dublin 2

www.ria.ie

Copyright (C) 2016 Royal Irish Academy

ISBN: 978-1-908996-88-6

The articles in this book are open access and distributed under the terms of the Creative Commons Attribution 4.0 licence, which permits unrestricted use, distribution and reproduction in any medium, provided the original authors and source are credited. To view a copy of this licence, visit https://creativecommons.org/licenses/by/4.0/

Except where noted:

Geological mapping for Northern Ireland / Tellus data are provided by the Geological Survey of Northern Ireland.

Geological mapping for Ireland / Tellus Border data are provided by the Geological Survey of Ireland.

Topographic mapping for Northern Ireland is derived from Land and Propery Services Open Data and contains public sector information licensed under the Open Government Licence v3.0. (http://www.nationalarchives.gov.uk/doc/open-governmentlicence/version/3/).

Topographic mapping for Ireland is derived from Ordnance Survey of Ireland Open Data (https://creativecommons.org/licenses/by/4.0/legalcode).

While every effort has been made to contact and obtain permission from holders of copyright, if any involuntary infringement of copyright has occurred, sincere apologies are offered, and the owner of such copyright is requested to contact the publisher.

British Library Cataloguing-in-Publication Data. A catalogue record is available from the British Library.

Design: Alex Donald, Geological Survey of Northern Ireland.

Index: Brendan O'Brien.

Printed in Poland by L\&C Printing Group. 


\section{Table of Contents:}

\section{Prelim}

DOI: https://doi.org/10.7486/DRI.b851k323d

\section{Chapter 1}

The Tellus geosciences surveys of the north of Ireland: context, delivery and impacts

DOI: https://doi.org/10.7486/DRI.st74s528d

\section{Chapter 2}

The Tellus airborne geophysical surveys and results DOI: https://doi.org/10.7486/DRI.t148tx96z

\section{Chapter 3}

The Tellus geochemical surveys, results and applications

DOI: https://doi.org/10.7486/DRI.t722wq645

\section{Chapter 4}

Stakeholder engagement for regional geoscientific surveying: the Tellus Border communications campaign

DOI: https://doi.org/10.7486/DRI.w089fr763

\section{Chapter 5}

Mineral resources and Tellus: the essential balance DOI: https://doi.org/10.7486/DRI.wd37kb12s

\section{Chapter 6}

Gold exploration in the north of Ireland: new targets from the Tellus Projects

DOI: https://doi.org/10.7486/DRI.wh24m696v

\section{Chapter 7}

Using soil geochemistry to investigate gold and base metal distribution and dispersal in the glaciated north of Ireland

DOI: https://doi.org/10.7486/DRI.wm11n3806

\section{Chapter 8}

Critical metals for hightechnology applications: mineral exploration potential in the north of Ireland DOI: https://doi.org/10.7486/DRI.wp98p0649

\section{Chapter 9}

A natural laboratory for critical metals investigations in the Mourne Mountains granites

DOI: https://doi.org/10.7486/DRI.cc08ww45f

\section{Chapter 10}

Geothermal potential of granitic rocks of the Mourne Mountains

DOI: https://doi.org/10.7486/DRI.ff36jm09f

\section{Chapter 11}

Shape and intrusion history of the Late Caledonian

Newry Igneous Complex, Northern Ireland

DOI: https://doi.org/10.7486/DRI.2v248822m

\section{Chapter 12}

Using Tellus data to enhance targeting of volcanogenic massive sulphide mineralisation in the Tyrone Igneous Complex

DOI: https://doi.org/10.7486/DRI.5x226w262

\section{Chapter 13}

The geological significance of electrical conductivity anomalies of the Ordovician- Silurian Moffat Shale Group, Northern Ireland

DOI: https://doi.org/10.7486/DRI.6m31f4149

\section{Chapter 14}

Faults, intrusions and flood basalts: the Cenozoic structure of the north of Ireland

DOI: https://doi.org/10.7486/DRI.90205h306

\section{Chapter 15}

Information for agriculture from regional geochemical surveys: the example of soil $\mathrm{pH}$ in the Tellus and Tellus Border data

DOI: https://doi.org/10.7486/DRI.dv14c8060

\section{Chapter 16}

An ecohydrological investigation of wetlands in the border counties of Ireland: a framework for a holistic understanding of wetland systems DOI: https://doi.org/10.7486/DRI.hd775d90j 
Chapter 17

Assessing nutrient enrichment risk to groundwaterdependent ecosystems in the border counties of Ireland DOI: https://doi.org/10.7486/DRI.k356pk18j

\section{Chapter 18}

Mapping the terrestrial gamma radiation dose

DOI: https://doi.org/10.7486/DRI.k930rb86z

\section{Chapter 19}

Soils and their radiometric characteristics

DOI: https://doi.org/10.7486/DRI.mp495t62g

\section{Chapter 20}

Modelling in-house radon potential using Tellus data and geology to supplement inhouse radon measurements

DOI: https://doi.org/10.7486/DRI.ns06hm86z

\section{Chapter 21}

Determining geochemical threshold values from the Tellus data sets: the examples of zinc and iodine| DOI: https://doi.org/10.7486/DRI.r2087418g

\section{Chapter 22}

Identification of the geochemical signatures of diffuse pollution in the Tellus Border soil data set, using source apportionment

DOI: https://doi.org/10.7486/DRI.wh24m698d

\section{Chapter 23}

Stream sediment background concentrations in mineralised catchments in Northern Ireland: assessment of 'pressures' on water bodies in fulfilment of Water Framework Directive objectives DOI: https://doi.org/10.7486/DRI.x633tf86g

\section{Chapter 24}

Mapping metallic contamination of soils in the Lower Foyle catchment

DOI: https://doi.org/10.7486/DRI.9k42bv355

\section{Chapter 25}

Refining the human health risk assessment process in Northern Ireland through the use of oral bioaccessibility data

DOI: https://doi.org/10.7486/DRI.9p29cr199

\section{Chapter 26}

Combining environmental and medical data sets to explore potential associations between environmental factors and health: policy implications for human health risk assessments

DOI: https://doi.org/10.7486/DRI.9s16dn03n

\section{Chapter 27}

Mapping a waste disposal site using Tellus airborne geophysical data

DOI: https://doi.org/10.7486/DRI.9w03fh87q

\section{Chapter 28}

The use of aero-magnetics to enhance a numerical groundwater model of the Lagan Valley aquifer, Northern Ireland

DOI: https://doi.org/10.7486/DRI.9z90gd711

\section{Chapter 29}

Carbon sequestration in the soils of Northern Ireland: potential based on mineralogical controls DOI: https://doi.org/10.7486/DRI.b277h9556

\section{Chapter 30}

Spatial distribution of soil geochemistry in geoforensics DOI: https://doi.org/10.7486/DRI.b564j6392

\section{End matter}

DOI: https://doi.org/10.7486/DRI.bc38m007j 